\title{
MANUFACTURE OF A NEW MACHINE FOR TRANSPLANTING SUGAR CANE CROP
}

\author{
EL-SAYED, G. H. ${ }^{1}$, A. M. ELZOHIERY ${ }^{2}$, M. A. ELTAWIL ${ }^{3}$, A. Y. MORAD ${ }^{2}$ \\ and M. A. ABOUEGELA ${ }^{1}$
}

1. Agric. Eng. Res. Inst. ARC, Dokki, Giza .

2. Fac. of Agric., Damanhour Univ.

3. Fac. of Agric., Kafr El-Sheikh Univ.

(Manuscript received 24 March 2014)

\begin{abstract}
Sugar cane is a labor intensive crop, where the most of the cane operations are carried out manually and the use of machinery is limited only for land preparation. The present study aims to manufacture a new prototype machine for transplanting sugar cane crop. Electronic circuit and servo motor control the movement and orientation of carriage belt of transplanting, whenever the infrared rays control the movement of seedling and determine their positions of transplanting tray. Timeliness of opening and closing has been adjusted by precisely by electronic air valves.

The experimental work was carried out at Etay Elbaroud Agricultural Research Station, Behera Governorate. Performance of the machine was evaluated under four forward speeds $(0.6,0.9,1.2$ and $1.5 \mathrm{~km} / \mathrm{h})$ and three seedling spaces $(27,37$ and $47 \mathrm{~cm})$. The results indicated evaluated that the highest value of longitudinal scattering and transverse scattering were 4.1 and $3.7 \mathrm{~cm}$ at forward speed of $1.5 \mathrm{~km} / \mathrm{h}$. While the highest value of energy consumption and transplanting efficiency were 26.49 $\mathrm{kW} . \mathrm{h} / \mathrm{fed}$ and $94.1 \%$ at forward speed of $0.6 \mathrm{~km} / \mathrm{h}$. On the other hand, missing, floating and dead seedlings increased as forward speed and seedlings spacing increased. The highest values of missing, floating and dead seedlings were $3.8,3.5$ and $3.7 \%$ at forward speed of $1.5 \mathrm{~km} / \mathrm{h}$ and at seedling space $47 \mathrm{~cm}$.
\end{abstract}

Keywords: Electronic valve, sensor, efficiency, energy, seedlings and scattering.

\section{INTRODUCTION}

Sugar cane, Saccharum officinarum L., is considered the main source for sugar production in Egypt and in an over the world. In Egypt sugar cane is planted in the Upper Egyptian for two seasons namely autumn and spring. Sugar cane productivity in Egypt comes at the fore in the world. The Productivity of sugarcane was reached to about 50.4 tons/fed on the basis of the growth season (12 months). The cultivated area of sugarcane in season 2012 was about 330000 Fed. (Agricultural Statistics 2012). Egypt ranks fourth in terms of sugar consumption per capita by $34 \mathrm{~kg}$ annually, after Brazil, the European Union and the United States. 
Since planting of sugarcane is done by vegetatively propagation (cane setts), there are many obstacles facing the planting process. The long interval between planting and emergence, the slow seedling growth, the wider row spacing, liberal fertilizer applications during planting and frequent irrigation during the early crop season are the main factors which upholding weed growth between the sugarcane rows. Sugar cane takes about 6-8 weeks to complete its sprouting and further 80-90 days its phase after planting (Malavla, et. al. 1991).

The yields of sugarcane could be increased considerably if optimum number of millable cane per area could be ensured with the existing cane varieties. This can be achieved by maintaining a uniform plant population per unit area. The potential millable cane per unit area can be obtained by using spaced transplanting technique (Imam et. al., 1982 and Rahman et. al., 2003).

In tropical and eastern counties, transplanting plant material in seedling stage is a common agricultural practice. Transplanting which implies the proper spacing of plants has become an acceptable practice in many agricultural enterprises (Rahman et. al., 2003).

Settling transplanted cane reduced 33\% (fresh weight) and 34\% (dry weight), and $43 \%$ (fresh weight) and $42 \%$ (dry weight) of weed at weeding and at the harvesting time, respectively, compared with sett planted cane. Tiller, millable cane and stalk length were reduced by $24 \%, 36 \%$ and $45 \%$, respectively in sett planted cane compared with settling transplanted cane. The settling transplanted cane increased the total stalk dry weight, the total shoot dry weight and the yield of cane by $79 \%, 69 \%$ and $85 \%$, respectively over sett planted cane (Yukio et. al., 1994).

Sugar cane is a labour intensive crop, which requires about 250 to 400 labour mandays per hectare. Most of the cane operations are carried out manually and the use of machinery is limited only for field preparation. The human labor cost constitutes more than $50 \%$ for labor intensive sugarcane crop.

Due to the scarcity of labourers, there is an urgent need to mechanically transplant sugarcane seedlings. After 4 years testing, evaluating and modifying the RT-2 vegetable transplanter (Lannen Company, Finland) was considered suitable for sugarcane seedling transplanting. Compared with manual transplanting, the mechanical transplanting of seedlings saves about $50 \%$ in labour costs (Wang and change, 1998).

Morad et. al. (2010) studied the effect of forward speed on longitudinal and transverse dispersion under two spacing rows. They found that, increasing forward speed from 2.5 to $3.88 \mathrm{~km} / \mathrm{h}$, increased longitudinal dispersion from 2.47 to $2.88 \mathrm{~cm}$ and from 2.66 to $3 \mathrm{~cm}$ for 20 and $30 \mathrm{~cm}$ spaces between plants, respectively. Also, 
transverse dispersion increased from 8 to $12.12 \mathrm{~cm}$ and from 9.46 to $12.37 \mathrm{~cm}$ under the same previous conditions. El-Sheikha (1989) mentioned that, there are three common types of transplanting systems; conventional hand transplanting, manual feeding (transporting mechanism with disc types or dick with grabs) and power feeding. Conventional hand transplanting is slow and costly. Also, power-transplanting machines are expensive for small Egyptian farmers.

Drees (2005) stated that the optimum conditions for the mechanical transplanting were $1.25 \mathrm{~km} / \mathrm{h}$ forward speed, spacing seedlings of $30 \mathrm{~cm}$ and seedlings age of 60 days. Genaidy (2008) evaluated the performance of small cotton transplanter, which consisted of disc, pocket arrangement with spring holders. Results indicated that the highest value of both theoretical and actual field capacities were 0.256 and 0.165 fed/h at forward speed of $1.5 \mathrm{~km} / \mathrm{h}$. Where in، the highest values of field efficiency and transplanting efficiency were $83 \%$, and $94.3 \%$, respectively at energy requirement of $76.8 \mathrm{~kW} . \mathrm{h} / \mathrm{fed}$.

Chaney et. al. (1986) developed an automatic control system for a sugarcane planter. A planter was equipped with an automatic control system for cane feed to eliminate the need for an operator to ride on the planter. Three sensing methods were tested: sensing pressure in the hydraulic line to the drum motor, sensing the mass of cane falling onto a flap in the discharge area and a photocell to count the rate of stalks falling from the planter. Each of these sensing systems controlled the table feed and could also control the speed of the drum. Varying the drum speed proved to be unnecessary. The pressure sensing system was the most effective, since it gave uniformity comparable with that obtained with an experienced operator and manual control.

Ramanand et. al. (2007) indicated that, effect of transplanting spacing on growth and yield of tissue culture raised crop of sugarcane. The effects of spacing on the growth and yield of micro propagated plants of sugarcane (cv. CoS 99259) were studied in Shahjahanpur, Uttar Pradesh, India, during 2006-07. Tissue-cultured

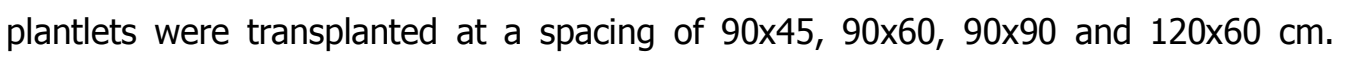
Results indicated that, plant growth, number of tillers, number of millable canes, cane height and cane yield were greatest under a spacing of $90 \times 60 \mathrm{~cm}$. Thus, this spacing was the most suitable for transplanting tissue-cultured plantlets of sugarcane.

The literature survey indicated the remarkable reduction of crop yield for competition between weeds and crops at early stage of growth. Settling transplanting system may be one of the ways to reduce the competition between weed and sugarcane at early stage of growth. 
Mechanization of planting sugarcane is facing a big challenge, since there is no transplanting machine currently available in the market. In addition there is a lack of information about sugarcane mechanization in Egypt.

From the foregoing, i) It must find a way suitable for transplanting sugarcane in order to reduce the amount of used sugarcane setts. ii) Provide a large amount of water used in irrigation and process during the germination period in the nursery (4-5 irrigations). iii) Provide an occupancy time for sustainable land up to two and a half months added to the previous crop or for good service.

Therefore this investigation aims at design, manufacture and evaluate the performance of new developed machine to suit transplanting sugarcane crop, based on electronic system controls.

\section{MATERIALS AND METHODS}

\section{Infield experimental site:}

The experiments were carried out in the premises of Etay Elbaroud Agricultural Research Station, Behera Governorate during agriculture season of 2013. The cane variety of $\mathrm{C} 9$ is used

\section{New transplanting prototype.}

The new prototype of transplanting machine was fabricated locally at the workshop of Rice Mechanization Center, Kafr El-Sheikh Governorate. The main idea is the electronic circuit and servo motor control the movement and orientation of carriage belt of transplanting, whenever the infrared rays control the movement of seedling and determine their positions of transplanting tray. Timeliness of opening and closing has been adjusted by precisely by electronic air valves. The feature of the new fabricated machine is that it has a simple mechanism which can meet the Egyptian farmers' requirements.

\section{Power source:}

Kubota motor model 6206 is used as the power source. Technical specifications presented in Table 1.

Table 1.The technical specifications of power source.

\begin{tabular}{|l|l|}
\hline Items & Specification \\
\hline Type & Kubota model 6206 \\
Made & Japan \\
Type of drive & 2 W.D. \\
Engine & Otto \\
Fuel & Gasoline \\
Number of cylinder & 1 \\
Engine power at $2500 \mathrm{rpm}$ & $6 \mathrm{hp}(4.41 \mathrm{~kW})$ \\
Cooling system & Air \\
\hline
\end{tabular}




\section{Developed transplanting unit:}

The general specifications of the transplanting unit are main overall dimensions of $1250 \mathrm{~mm}$ length, $850 \mathrm{~mm}$ width, $850 \mathrm{~mm}$ height and $60 \mathrm{~kg}$ overall mass. Feeding the seedlings were done using a conveyor belt operated by servo motor which controls its speed, starting and stopping positions. Compressed air through electronic valves can open and close the transplanting box in the exact timing accurately

In case of orienting the seedlings from nursery to the main field, the developed transplanting unit needs two labourers to fulfill the required work. One labourer to steering the transplanter while the other one will feed the seedlings to the conveyer belt. The sketched plan and side views of transplanting unit are shown in Figs. ( 1 and 2 ) show side and plan viewer of conveyor belt. The main components of the transplanting unit are depicted in Fig. 3.

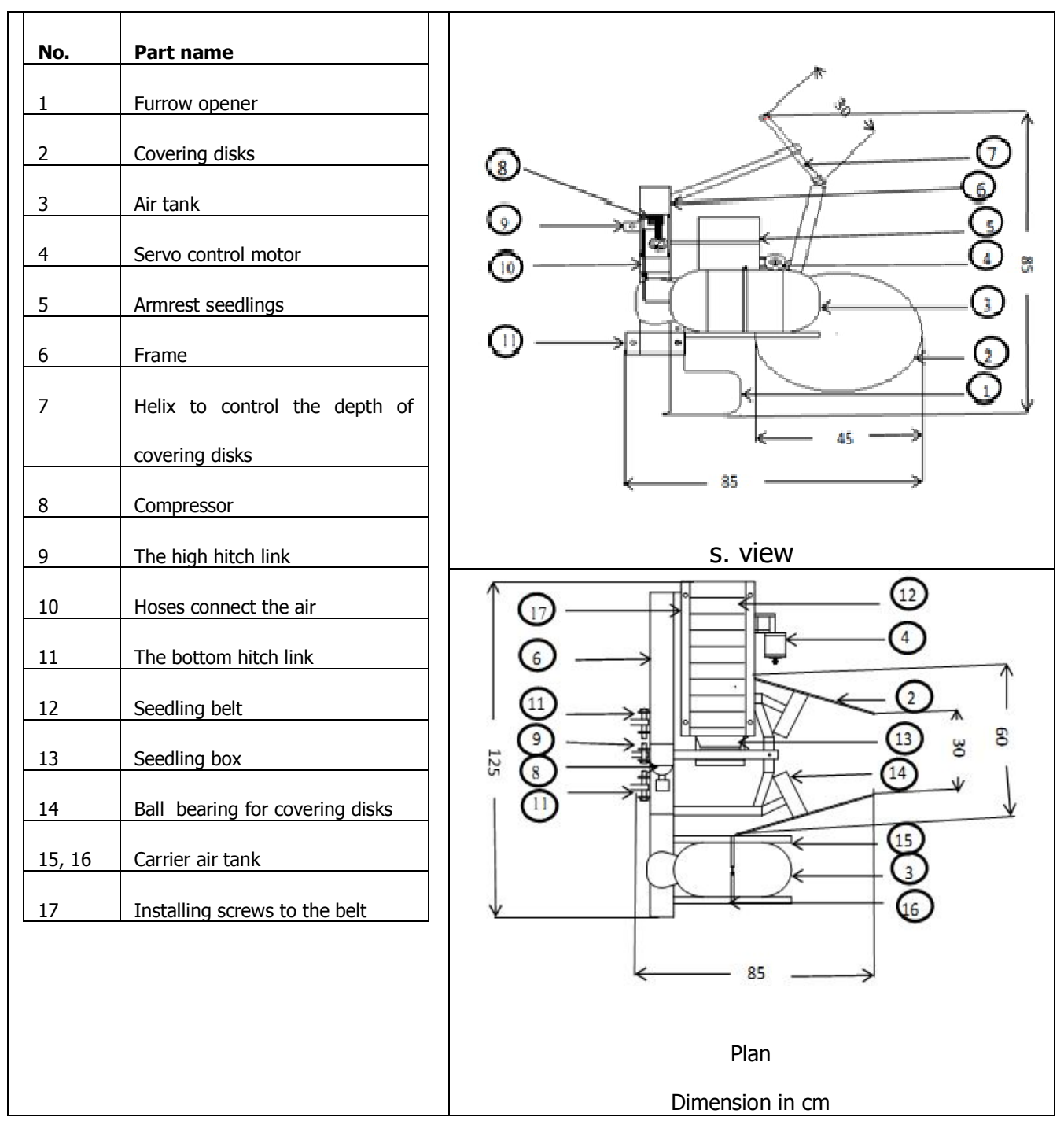

Fig.1. The schematic plan and side views of the transplanting unit. 


\section{Feeding unit:-}

The feeding unit is consisted of leatherette flat belt of $120 \mathrm{~cm}$ length, $20 \mathrm{~cm}$ width and $0.5 \mathrm{~cm}$ thickness. The belt is mounting on two drums each drum has $10 \mathrm{~cm}$ diameter, $20 \mathrm{~cm}$ length and supported with ball bearing of $20 \mathrm{~mm}$ diameter. The central distance between the two drums is $50 \mathrm{~cm}$. To ensure regular feeding of seedlings, there are 20 conical cans made from aluminum and fixed on the conveyer belt. These pockets have been formed in $U$ shape $(20 \mathrm{~cm}$ length, $5 \mathrm{~cm}$ height, $3 \mathrm{~cm}$ at the bottom and $5 \mathrm{~cm}$ at the top) and used to transfer the seedlings that feed by labour to the seedling drop box. A servo motor is used to operate an electronic system to control the conveyer belt speed and its positions. Infrared is used to control the movement of seedlings from the conveyer and determine their positions until they reach the transplanting box. In order to drop the seedlings in exact time, the transplanting box is opened and closed accurately using compressed air through electronic valves

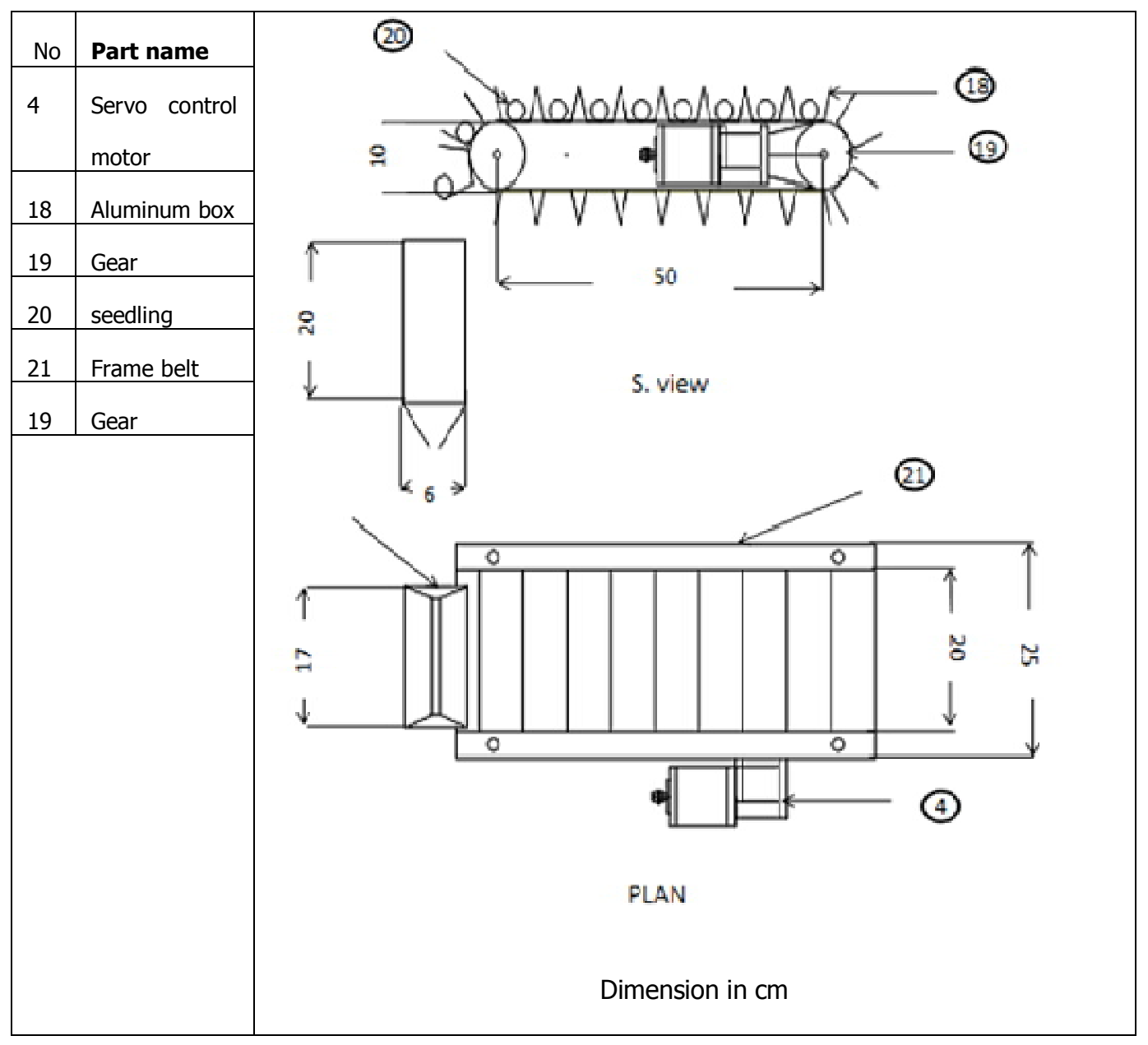

Fig.2. Side and plan views of conveyor belt of transplanting unit. 


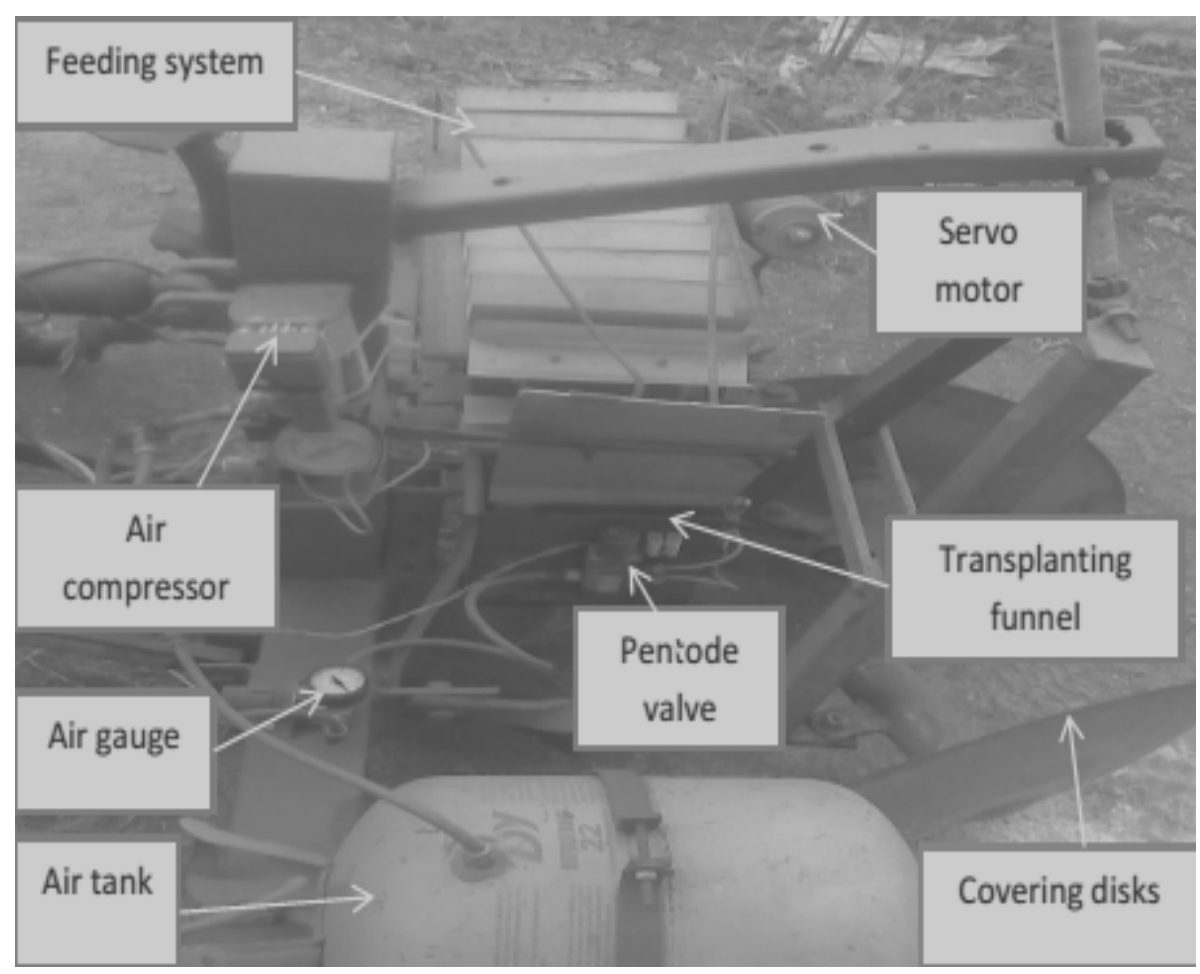

Fig. 3. The main components of the developed transplanting unit.

\section{Chisel furrow-opener.}

The developed transplanting unit is equipped with chose furrow-opener has $300 \mathrm{~mm}$ cutting width and $150 \mathrm{~mm}$ height. The furrow opener has the flexibility to move in vertical direction in order to select the proper depth that required for transplanting.

\section{Covering device.}

The covering device consists of two steel disks (Fig. 3). Each covering disk has concave shape with $45 \mathrm{~cm}$ diameter and $3 \mathrm{~mm}$ thickness. The covering device is attached to the main frame of transplanter using rectangular steel beam of $5 \times 2 \mathrm{~cm}$.

\section{Electronic cycle:}

The wheel diameter of the developed machine is $60 \mathrm{~cm}$, hence the wheel circumference is $188.4 \mathrm{~cm}$. For the developed machine, initially during the rotation of the ground wheel, the aperture distance that exists on the disc comes in front of toothed circular motion detector (Infrared sensor for measuring distance), which gives the motor ordered to operate. The order comes in the form of electric pulse equal to 12 volts and its time ranged from $1 / 1000 \mathrm{~s}$ to infinity. Thereafter the seedling carrier (aluminum can) comes in front of the positioning bulb (reception). Hence, the light reflected to the receiver, which recognizes the frequency immediately and sends a signal to stop the engine within $1 / 1000 \mathrm{~s}$. When the engine stopped, it takes about 
$0.15-0.2 \mathrm{~s}$, and then released a signal from the electronic unit which is responsible for opening the transplanting can (Box). The time required for opening the transplanting box can be adjust to $0.2-0.6 \mathrm{~s}$. The electronic unit gives an order for pentode valve to open the seedling box. The normal position of pentode valve is locked or closed position. In case of there is no reflected rays, there is an auxiliary circle which restart (revolves) the engine for a moment to come out from the rays reflection and wait for the response of the following reflection of the transplanting box. This circuit is working based on phase locked looped control movement.

\section{Air circulation:-}

Air cycle consists of DC air compressor (12-13.5 V, maximum ampere is $15 \mathrm{~A}$, max pressure is $150 \mathrm{psi}$, discharge is $35 \mathrm{l} / \mathrm{min}$ ) works by $12 \mathrm{~V}$ battery, air tank, air gauge, air regulator, pentode valve, non-return valve, piston ...etc. as shown in Fig. 4.

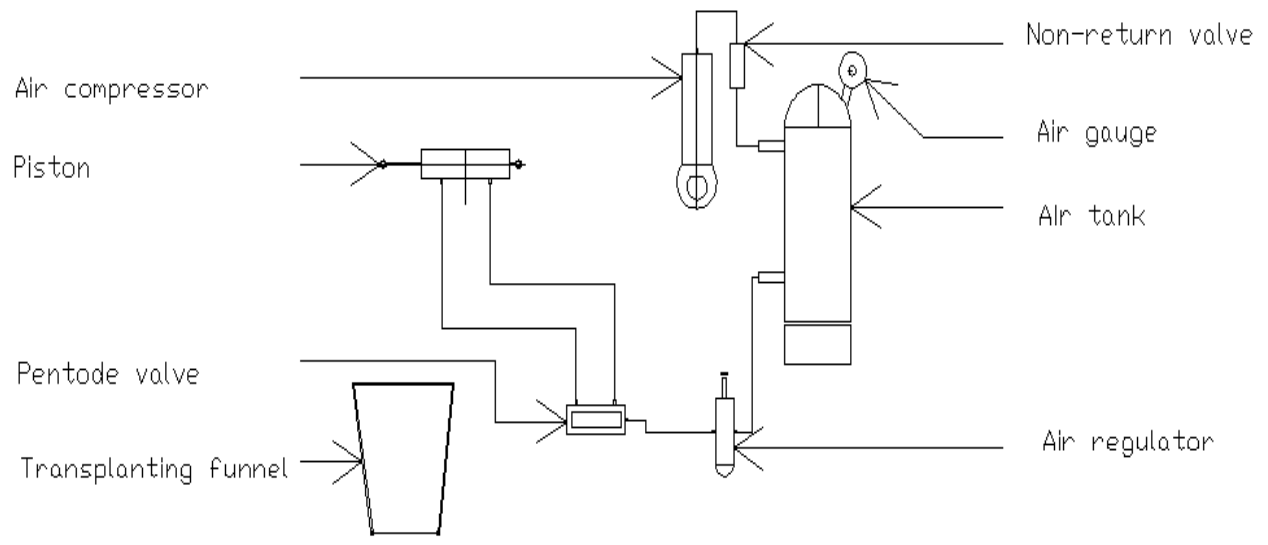

Fig.4. Main components of air circulation.

The compressor is used to compress air through air links to the air tank. The air pressure is controlled through a safety device which works to stop the compressor when the pressure in the air tank reaches to 4 bar. Pressure is going through the stages until be outreach to transplanting can which operates by air pressure (opening and closing). Initially air passes from compressor to pressure gauge and non-return valve then enters the air tank, which ends stopcock out through a combination of air pressure gauge, to another air tank and then to the pentode valve that controls the opening and closing transplanting can.

To evaluate the performance of the developed mechanical transplanter, the following variables were studied: forward speeds of $0.6,0.9,1.2$ and $1.5 \mathrm{~km} / \mathrm{h}$. seedlings spacing of 27,37 and $47 \mathrm{~cm}$ at seedling age of 70 days. Experimentations were carried out to evaluate the effect of studied variables on the following 
parameters: Longitudinal and transverse scattering; missing, floating and dead seedlings; specific fuel consumption; energy consumption and transplanting efficiency. Table 2 shows properties of cane stalk before bud separation.

Table 2. Some physical and mechanical properties of cane stalk before bud separation.

\begin{tabular}{|l|c|c|c|}
\hline Properties & Max & Min & Mean \\
\hline Stalk length , L, cm & 210 & 170 & 190 \\
Stalk diameter ,D, cm & 3 & 1.5 & 2.25 \\
Stalk mass ,M, kg & 1.3 & 0.75 & 1.01 \\
The number of buds of stalk & 16 & 8 & 12 \\
The stalk curvature , $\mathrm{r}_{\mathrm{c}} \mathrm{cm}$ & 79.7 & 72 & - \\
Cane hardness , $\mathrm{F}_{\text {hard }}, \mathrm{N}$ & 200.4 & 120.4 & 165 \\
\hline
\end{tabular}

\section{Measurements and calculations}

\section{Longitudinal and transverse scattering:}

The dispersion of seedling about the center of row is determined according to the following formula (Stell and Torrie, 1980)

$$
\text { Scattering }=
$$

$$
\sqrt{\frac{\sum(x-\mu)^{2}}{N}}
$$

$\sum(x-\mu)^{2}$ The sum of squares of variance of seed scattering.

$\mathrm{N} \quad=$ The number of hills

\section{Missing hills percentages:}

The percentage of vacant hills was calculated according to Hossary et al. (1980) by using following formula.

$$
M R=\left(\frac{N_{R}}{N_{t h}}\right) \times 100
$$

Where:

$$
\begin{aligned}
& M R=\text { vacant hills, percentage, } \\
& N_{R}=\text { Number of vacant hills } / 30 \mathrm{~m} \text { length and } \\
& N_{\text {th }}=\text { Number of the theoretical hills } / 30 \mathrm{~m} \text { length }
\end{aligned}
$$

\section{Specific fuel consumption (SFC),}

Specific fuel consumption as function of the amount of work being done by the engine defined as follows:

$$
\mathrm{SFC}=\frac{M_{F}}{P}
$$


Where:

$\mathrm{SFC}=$ Specific fuel consumption in $\mathrm{kg} / \mathrm{kW} \cdot \mathrm{h}$

$M_{f}=$ Fuel consumption rate in $\mathrm{kg} / \mathrm{h}$ and

$\mathrm{P}=$ Power in $\mathrm{kW}$

\section{The power requirement}

Power required is calculated using the measured fuel during transplanting operation under different variables of the study according to Embaby (1985):

$P_{\text {required }}=\left(F_{c} / 3600\right) \times F_{f} \times$ L.C.V. $\times 427 \times \eta_{\text {th }} \times \eta_{m} \times(1 / 75) \times(1 / 1.36)$

Where:

$\mathrm{P}_{\text {required }}=$ power requirement, $\mathrm{kW}$;

$\mathrm{F}_{\mathrm{c}}=$ fuel consumption, $\mathrm{l} / \mathrm{h}$;

$\mathrm{F}_{\mathrm{f}}=$ density of fuel, for gasoline fuel $=0.72 \mathrm{~kg} / \mathrm{l}$;

L.C.V. = lower calorific value of fuel, $10000 \mathrm{kcal} / \mathrm{k} \mathrm{g}$;

427 = thermo-mechanical equivalent, kg. $\mathrm{m} / \mathrm{kcal}$;

$\eta_{\text {th }}=$ thermal efficiency of the engine, $35 \%$ and

$\eta_{m}=$ the mechanical efficiency of engine, $80 \%$.

\section{Energy consumption}

$$
\text { Energy consumption }=\frac{P}{F \cdot C_{e f}} k W . h / f e d
$$

Where:

$P=$ power requirement $\mathrm{kW}$, and

$F \cdot C_{e f}=$ Effective field capacity fed/h.

\section{Transplanting efficiency:}

The transplanting efficiency was measured according to RNAM (1991) using the following equation:

$$
\eta_{\mathrm{t}}=\frac{1-\left(N_{d}+N_{m}+N_{f}\right)}{N_{t}} \times 100
$$

Where:

$\eta_{\mathrm{t}}=$ Transplanter efficiency, $\%$;

$\mathrm{N}_{\mathrm{t}}=$ Theoretical number of seedling per unit length;

$\mathrm{N}_{\mathrm{d}}=$ Number of dead seedling, \%;

$\mathrm{N}_{\mathrm{m}}=$ Number of missed seedling, \%;

$\mathrm{N}_{\mathrm{f}}=$ Number of floating seedling, $\%$ and 


\section{RESULTS AND DISCUSSION}

\section{Effect of different variables on longitudinal and transverse scattering, (cm)}

As shown in Fig. 6, the longitudinal and transverse scattering increased as both of forward speed and as transplanting spaces increased. The highest values of the longitudinal and transverse scattering were 4.1 and $3.7 \mathrm{~cm}$ at forward speed of $1.5 \mathrm{~km} / \mathrm{h}$. On the other hand the lowest values were 1.9 and $1.5 \mathrm{~cm}$ at $0.6 \mathrm{~km} / \mathrm{h}$ respectively.

Meanwhile, results indicated that, the highest values of the longitudinal and transverse scattering were 3.4 and $2.9 \mathrm{~cm}$ at seedling space of $47 \mathrm{~cm}$ while the lowest values were 2.6 and $2.1 \mathrm{~cm}$ at seedling distance of $27 \mathrm{~cm}$ respectively.

The recorded results revealed that by increasing seedlings space from 27 to $47 \mathrm{~cm}$, the longitudinal and transverse scattering increased by $46.87 \%$ (i.e. from 1.6 to $2.35 \mathrm{~cm}$ ) and $45.83 \%$ (i.e. from 1.2 to $1.75 \mathrm{~cm}$ ), respectively at the same forward speed of $0.6 \mathrm{~km} / \mathrm{h}$. The maximum values of longitudinal and transverse scattering were 4.55 and $4.15 \mathrm{~cm}$, respectively at seedling distance of $47 \mathrm{~cm}$ and $1.5 \mathrm{~km} / \mathrm{h}$ (Fig. 6). While the minimum values of longitudinal and transverse scattering were 3.55 and $3.3 \mathrm{~cm}$, respectively at $27 \mathrm{~cm}$ seedling distance and $1.5 \mathrm{~km} / \mathrm{h}$. This would be attributed to the increase of slip and vibration caused by increasing forward speed. 
(a)

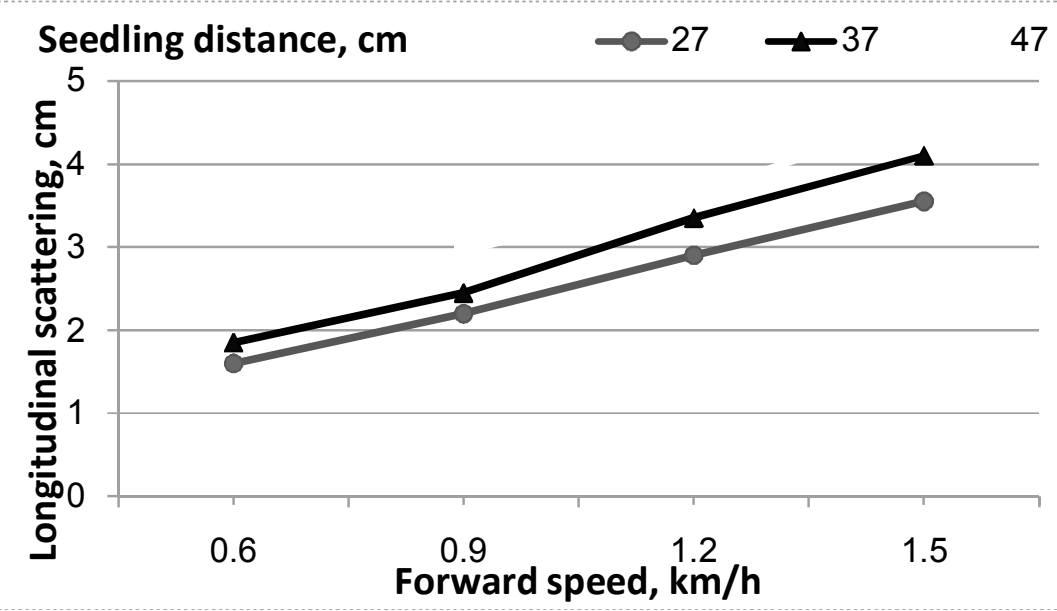

(b)

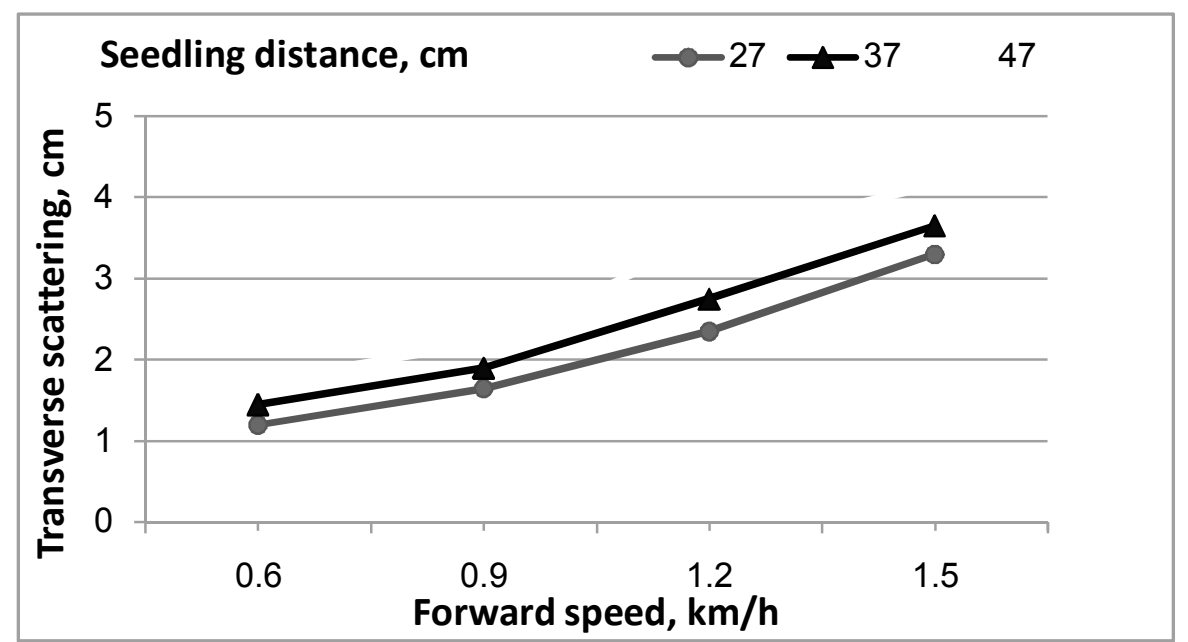

Fig. 6. Effect of forward speeds and seedling spaces on (a) longitudinal and (b) transverse scattering.

\section{Effect of seedling spaces and forward speed on missing seedling:}

The results showed in Fig. 7 revealed that by increasing seedlings spaces from 27 to $47 \mathrm{~cm}$, the missing seedlings decreased from 2.45 to $1.9 \%$ at the same forward speed of $0.6 \mathrm{~km} / \mathrm{h}$. The maximum and minimum values of missing seedlings of 4.3 and $3.4 \%$ were recorded at 47 and $27 \mathrm{~cm}$ seedling distance, respectively and forward speed of $1.5 \mathrm{~km} / \mathrm{h}$. This would be attributed to the increase of time that required for labourer to feeding the seedlings. 


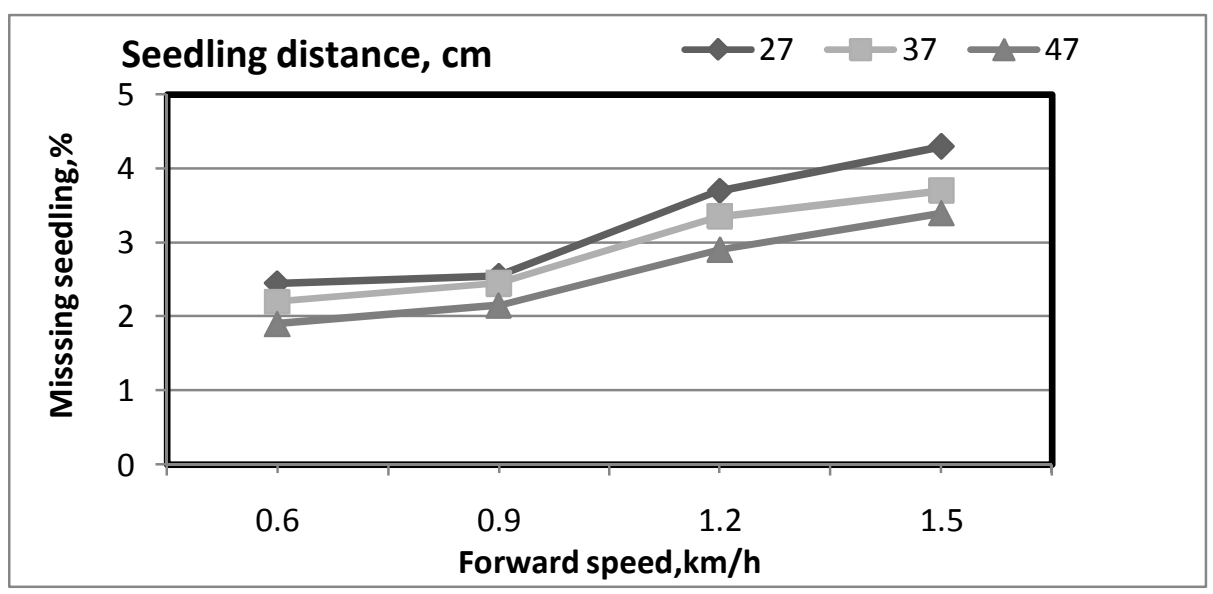

Fig. 7. Effect of forward speed and seedling distances on missing seedling.

\section{Effect of seedling spaces and forward speeds on floating seedling:}

From the recorded results, it is obvious that, the floating seedling increased as the seedling space and forward speed increased. Fig. 8 shows that by increasing seedlings distances from 27 to $47 \mathrm{~cm}$, the floating seedling increased from 1.65 to $2.3 \%$ at forward speed $0.6 \mathrm{~km} / \mathrm{h}$. The maximum and minimum values of floating seedlings of 3.75 and $3.25 \%$ were recorded at seedling spaces of 47 and $27 \mathrm{~cm}$, respectively and at forward speed of $1.5 \mathrm{~km} / \mathrm{h}$. This would be due to the decrease in actual number of seedlings per unit of area comparing with the theoretical number of seedling.

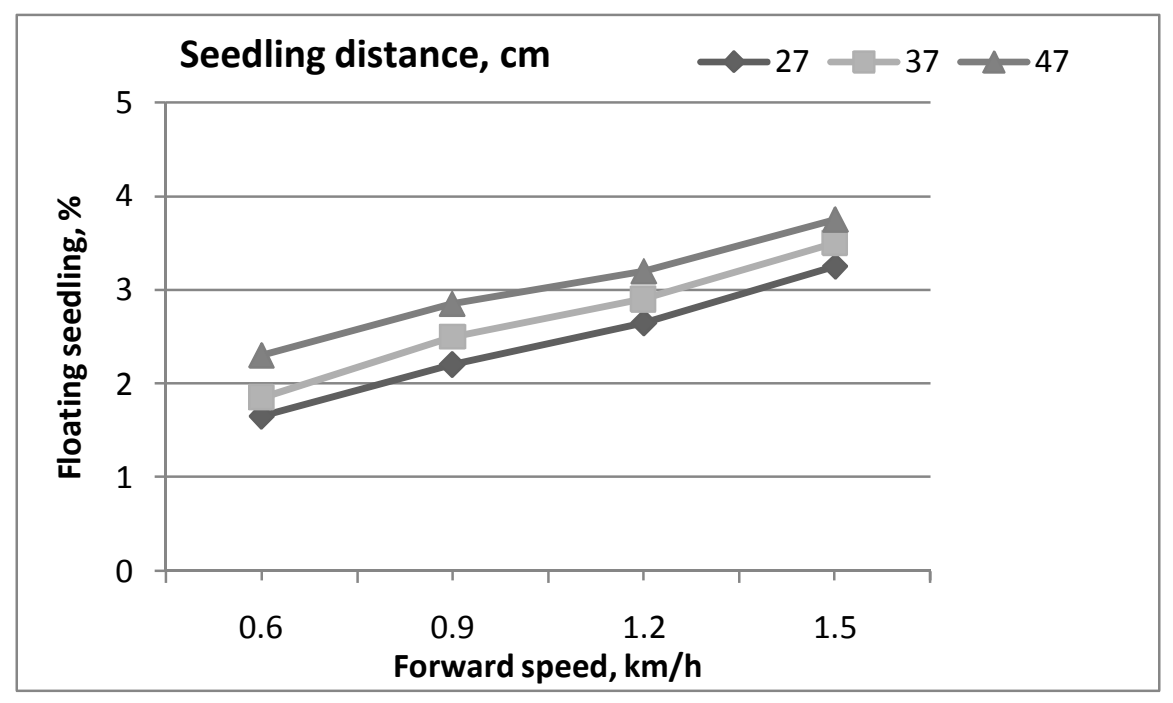

Fig. 8. Effect of forward speed and seedling spaces on floating seedlings. 


\section{Effect of seedling spaces and forward speeds on dead seedling:}

Observed results in Fig. 9 indicated that, the dead seedlings increased as the seedling spaces and forward speed increased. The recorded results revealed that by increasing seedlings spaces from 27 to $47 \mathrm{~cm}$, the dead seedling increased from 1.0 to $2.5 \%$ at the same forward speed of $0.6 \mathrm{~km} / \mathrm{h}$. The maximum and minimum values of dead seedlings of 4.35 and $3.2 \%$ were recorded at seedling spaces of 47 and $27 \mathrm{~cm}$ and at forward speed of $1.5 \mathrm{~km} / \mathrm{h}$. This attributed to decrease in actual number of seedling in the unit of area comparing with the theoretical number of seedling.

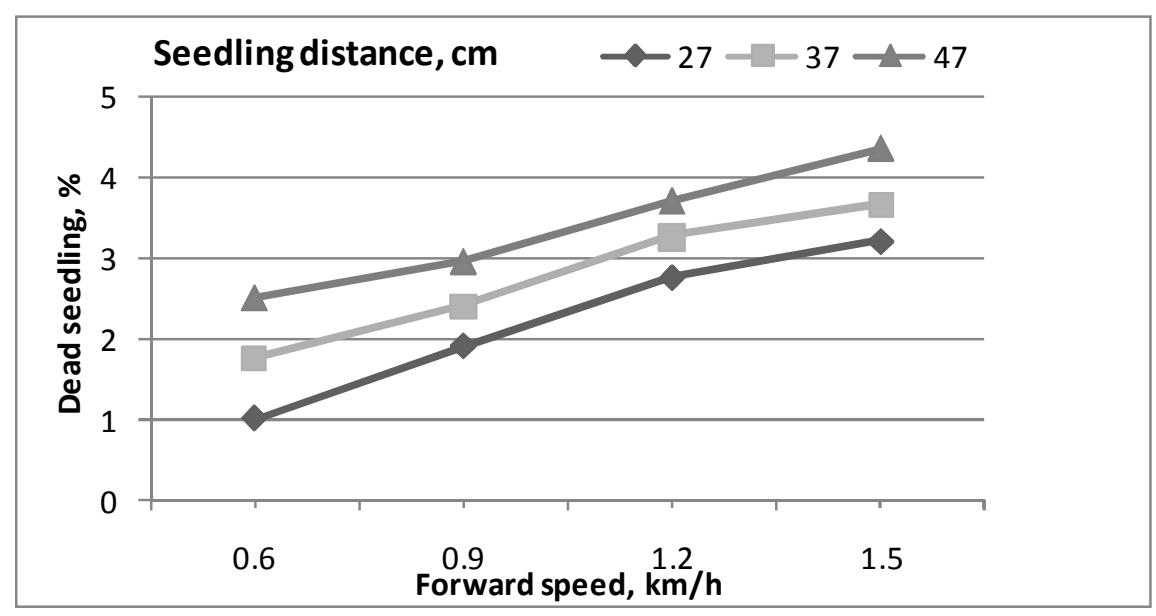

Fig.9. Effect of forward speeds and seedling spaces on dead seedling

\section{Effect of seedling spaces and forward speeds on power requirement:}

Fig. 10 indicated that, the power requirement decreased as the seedling distances increased for all forward speed. The recorded results revealed that by increasing seedlings distance from 27 to $47 \mathrm{~cm}$, the power requirement decreased from 2.8 to $2.5 \mathrm{~kW}$ at constant forward speed of $0.6 \mathrm{~km} / \mathrm{h}$. The maximum and minimum values of power requirement of 3.22 and $2.55 \mathrm{~kW}$ were recorded at 27 and $47 \mathrm{~cm}$ seedling distance and at forward speed $1.5 \mathrm{~km} / \mathrm{h}$.

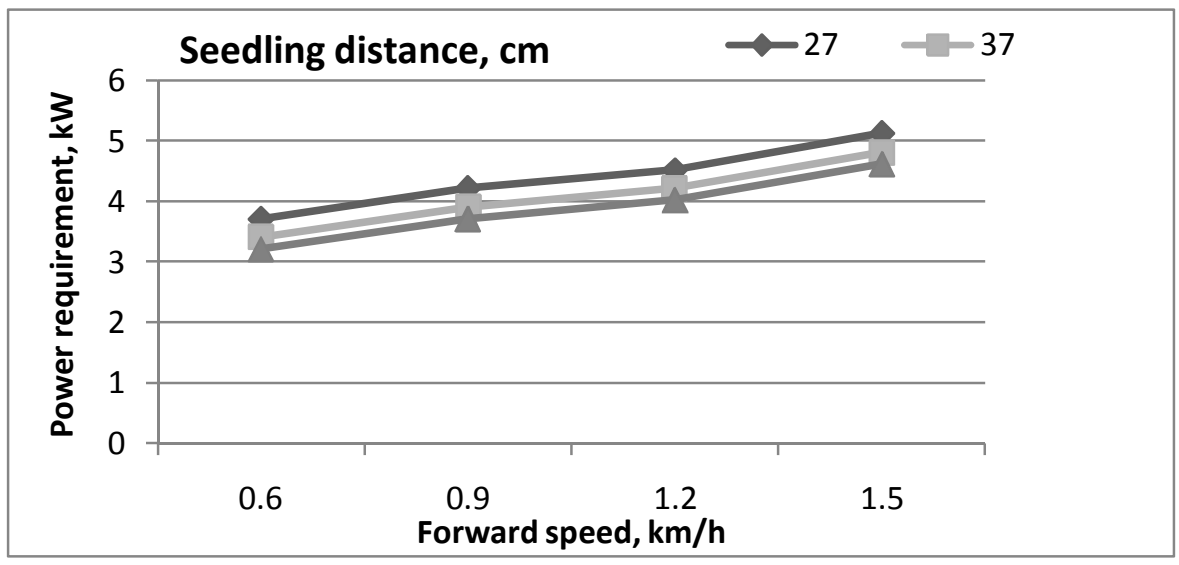

Fig.10. Effect of forward speeds and seedling spaces on power requirement. 


\section{Effect of seedling spaces and forward speeds on transplanting efficiency:}

Fig. 11 indicated that, by increasing seedlings space from 27 to $47 \mathrm{~cm}$, the transplanting efficiency decreased from 94.7 to $93.3 \%$ at forward speed of $0.6 \mathrm{~km} / \mathrm{h}$. The maximum and minimum values of transplantnig efficiency of 89.3 and $88.5 \%$ were recorded at 27 and $47 \mathrm{~cm}$ seedling space and at forward speed of $1.5 \mathrm{~km} / \mathrm{h}$.

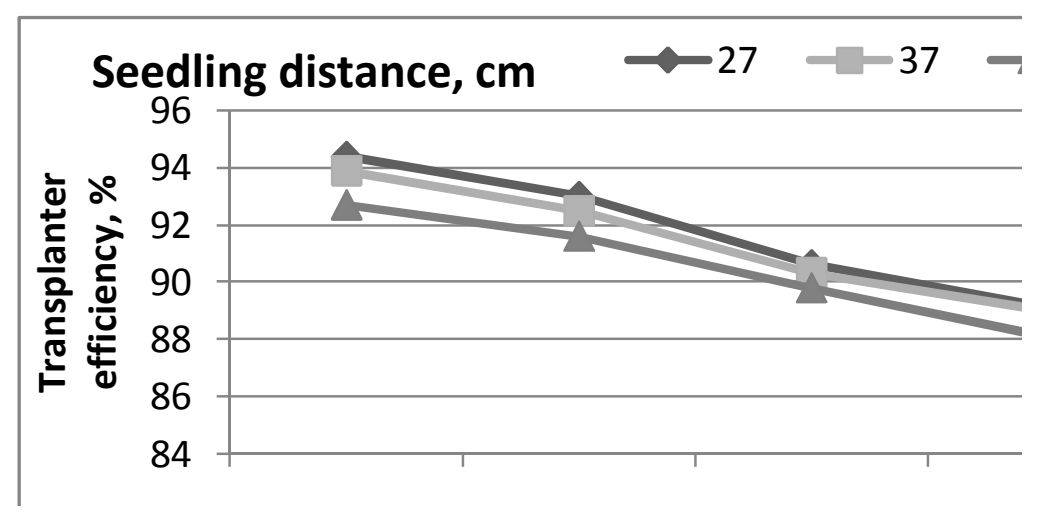

Fig.11. Effect of forward speeds and seedlings spaces on transplanting efficiency.

\section{CONCLUSION}

From the pevrous results the following conclusions are derived:

1. The longitudinal and transverse scattering increased as the seedling spaces and forward speeds increased. At seedling space of $27 \mathrm{~cm}$, since forward speed increased from 0.6 to $1.5 \mathrm{~km} / \mathrm{h}$, the longitudinal and transverse scattering increased from 1.2 to 3.3 and to 1.6 to $3.55 \mathrm{~cm}$, respectively.

2. At seedling distance $27 \mathrm{~cm}$, increasing forward speed from 0.6 to $1.5 \mathrm{~km} / \mathrm{h}$ led to increase the missing, floating and dead seedling from $(1.9,1.65 \mathrm{and} 1.0 \%)$ to $(3.4,3.25$ and $2.1 \%)$ respectively.

3. The maximum and minimum values of energy consumption of 21.62 and 9.7 $\mathrm{kW} . \mathrm{h} / \mathrm{fed}$ were recorded at 27 and $47 \mathrm{~cm}$ seedling space and at forward speed of $1.5 \mathrm{~km} / \mathrm{h}$.

4. The best transplanter efficiencies were recorded at $0.6 \mathrm{~km} / \mathrm{h}$ forward speed for all seedling space.

\section{REFERENCES}

1. Agricultural Statistics. 2012. Central Administration from Horticultural and Agricultural Crops. Economic Affairs Sector.

2. Chaney, P.P.; Parish, R.L.; Sistler, F.E. 1986. An automatic control system for a sugarcane planter. Applied-Engineering-in-Agriculture. 2(2): 51-54.

3. Drees, A. M. 2005. A study on mechanization of sugarcane planting. Ph.D. Thesis Agric. Eng. Dept. Fac. of Agric., Tanta Univ. 
4. El- Sheikha, M. A. 1989. The performance of transplanting machines with manual feeding. Misr J. Agric. Eng. 12(3):152-164.

5. Embaby, A. T. 1985. A comparison of different mechanization systems for cereal crop production. M. Sc. Thesis. Fac. of Agic. Cairo University.

6. Genaidy, M. A. I. 2008. Performance of A small cotton transplanter under Egyptian conditions. Misr J. Ag. Eng., 25(1): 1-14.

7. Hossary, A.M; N. M. El-Awady; A. I. Hashish and A. El- Beheiry. 1980. Rice transplanting Zagazig Univ. fac. Of Agric. Res. Bul. No. 154 sep: 9-15pp.

8. Imam, S.A.; A.H.M.D. Hossain, M.H. Rahman and M.N. Islam. 1982. A comparative study of variety performance in eight ecological zones. Bangladesh J. Sugarcane, 4: 7-13.

9. Malavla, D.D.; B.M. Dhabi; K.P. Patel; V.B. Rahman and H.D. Kavani. 1991. Studies on weed control in sugarcane. Indian Sugar. 41(5): 315-318.

10. Morad, M. M; M. KH. Afifi; H. M. Hekal and E. E. Abd-El Aaty. 2010. Development of a planting machine used under sub surface irrigation system. Misr J. Ag. Eng., January 27(1): 1 - 17.

11. Rahman, M.S.; Kuasha Mahmud; M.S. Hossain and M.Eunus. 2003. Effect of different types of settling of different varieties on the yield and yield contributing characters of sugar cane. Journal of Agronomy 3(1): 11-17.

12. Ramanand, N. S; Kureel, N.; Lal, M. and Singh, S.B. 2007. Effect of transplanting spacing on growth and yield of tissue culture raised crop of sugarcane.IndianSugar 57(3): 33-36.

13. RNAM. 1991. Agricultural machinery design data handbook, seeders and planter, Ec. and Soci. Commis. Asia and the Pacific: 17-20.

14. Stell, R. G. and S. H. Torrie. 1980. Principles and procedures of statistic. McGrawHill Company, N.Y.

15. Wang K.R. and Chang. Y. S. 1998. Transplanting sugarcane seedling with a vegetable transplanter. Report of the Taiwan Sugar Research institute. No. 160: 19-35.

16. Yukio Ishimine; M.A. Hossain; Keiji Motomura; Hikaru Akamine; Seiichi Murayama and S.M.M. Uddin. 1994. Comparative study of sett planting and settling transplanting system of sugarcane. Sci. Bull. Coll. Univ. Ryukyus. 41: 316-326. 


\section{تصنيع الة جديدة لشتل قصب السكر}

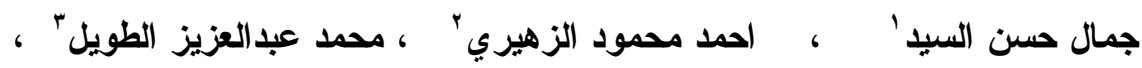

احمد يوسف مراد׳ ، محد عبدالجواد احمد'

$$
\begin{aligned}
& \text { 1 . معهز بحوث الهنسة الزراعية - الدقى - جيزة } \\
& \text { r r كلية الزراعة - جامعة دمنهور }
\end{aligned}
$$

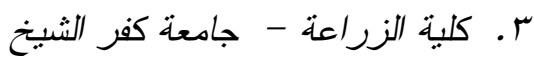

يعتبر محصول قصب السكر من المحاصيل الإستر اتيجية الهامة بالنسبة لجميع بلدان العالم

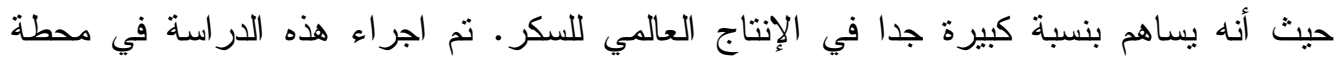

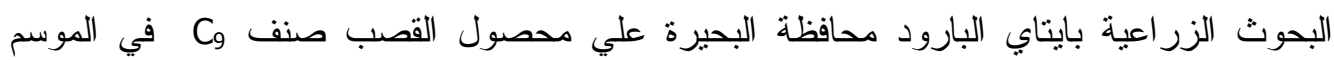

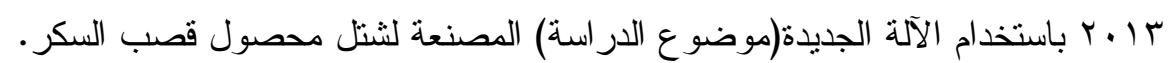

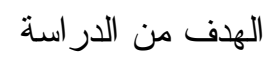

1-تصنيع وتقييم آلة جديدة لشتل محصول قصب السكر تعمل عن طريق موتور سيرفو يتم

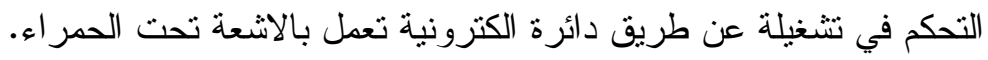

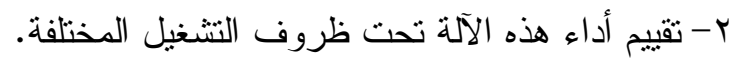

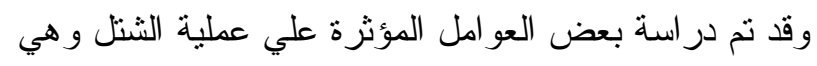

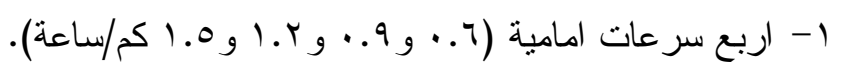

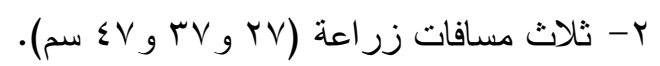

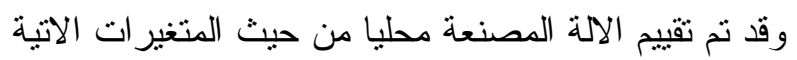

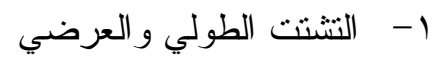

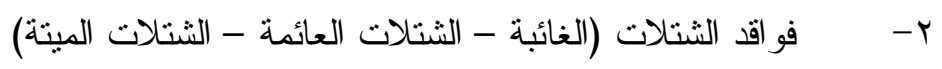

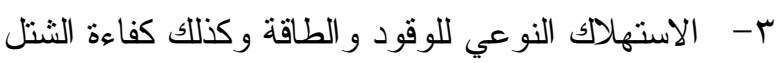

$$
\text { وقد تم التوصل للنتائج الآتية }
$$

1- يزداد النتتت الطولي و العرضي بزيادة السرة التهة الأمامية وكذلك بزيادة مسافة الشتل فعند

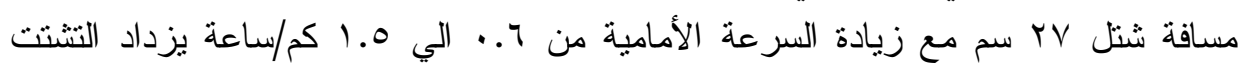

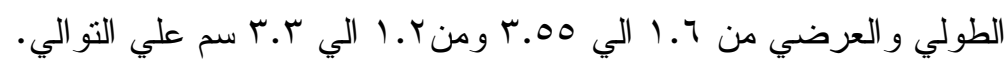
Y

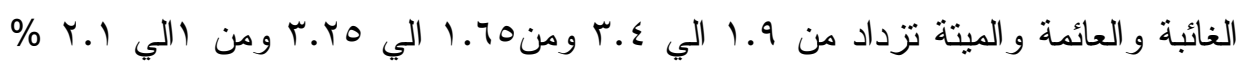
علي التو الي.

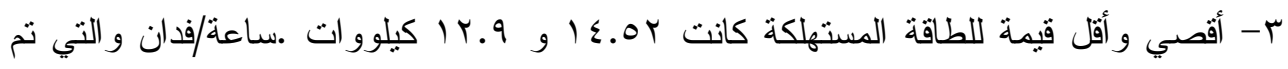

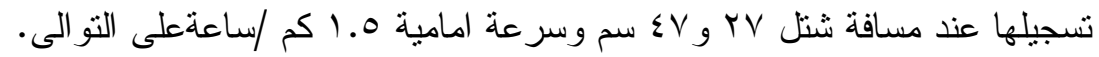

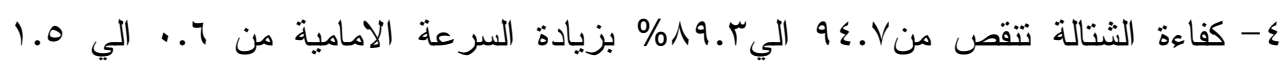

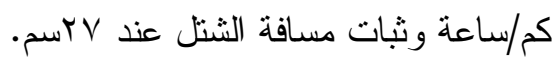

